\title{
EFFECT OF CINNAMOMUM ZEYLANICUM ESSENTIAL OIL ON QUALITY OF CHICKEN SAUSAGE
}

\author{
THABET M.GERGES ${ }^{1}$ and ABOU-ARAB N. M. ${ }^{2}$ \\ ${ }^{1 \& 2}$ Animal Health Research Institute (Benha Branch-Food Control Department)
}

Received: 8 March 2016; Accepted: 27 April 2016

\begin{abstract}
The purpose of the present investigation was to study the effect of Cinnamomum zeylanicum essential oil adding at two concentrations $(0.02 \%$ and $0.04 \% \mathrm{v} / \mathrm{w})$ on $\mathrm{pH}$, lipid oxidation, microbial growth and sensory characteristics of chicken sausage stored at $4{ }^{\circ} \mathrm{C}$ for 21 days. The antioxidant activities were compared to that of a standard synthetic antioxidant; butylated hydroxyanisole (BHA). The results declared that the $\mathrm{pH}$ values were not differing between the BHA-formulated sausage samples and samples containing $C$. zeylanicum essential oil ( $p>0.05)$. Incorporation of $C$. zeylanicum essential oil retard lipid oxidation process at the end of storage $(\mathrm{p}<0.05)$. The initial TBA value was $0.140 \pm 0.01 \mathrm{mg}$ malonaldehyde $/ \mathrm{Kg}$ sample. After 21 days of storage, it reached to $0.191 \pm 0.02 \mathrm{mg}$ malonaldehyde/Kg sample in BHA-formulated samples (T1), 0.227 $\pm 0.02 \mathrm{mg}$ malonaldehyde/Kg sample in $C$. zeylanicum essential oil $0.02 \%$ samples (T2) and averaged $0.153 \pm 0.02 \mathrm{mg}$ malonaldehyde/Kg sample in $C$. zeylanicum essential oil $0.04 \%$ samples (T3). All samples had lower TBARs values and adding $C$. zeylanicum essential oil decreased the lipid oxidation of samples. At storage day 21, sausage samples formulated with $C$. zeylanicum essential oil (T2 \& T3) maintained lower APC $\left(6.90 \pm 0.06\right.$ and $6.30 \pm 0.09 \log _{10}$ CFU/g, respectively) than the MPL, while APC in control samples (T1) exceeded the limit of $7 \log _{10} \mathrm{C}$-FU/g. Samples containing highest amount of $C$. zeylanicum essential oil (T3) had higher sensory score compared to control sample. The results suggest that $C$. zeylanicum essential oil, which might be seen more healthful than those of synthetic origin and through their combined antioxidant and antimicrobial effects, are potentially useful in preserving chicken sausage.
\end{abstract}

Key words: Cinnamomum Zeylanicum, Essential Oil, Quality of Chicken, Sausage

\section{INTRODUCTION}

There is a growing interest in the use of natural products in the human food and animal feed industries, as consumer resistance to synthetic additives is increasing (Ito et al., 1986). The use of natural additives has attracted attention; reportedly, natural compounds have antioxidant effects similar to or better than synthetic preservatives (Sebranek et al., 2005).

The use of plant essential oils as antioxidant and antimicrobial agents in processed foods is a promising alternative for synthetic compounds. The essential oils have been extensively used in food products, not only for their antibacterial, antifungal and antioxidant properties but also as food flavoring agents (Viuda-Martos et al., 2009). The main advantage of essential oils is that they can be used in

Corresponding author: Dr. THABET M.GERGES

E-mail address: magdy.thabet@yahoo.com

Present address: Animal Health Research Institute (Benha BranchFood Control Department) any food and are generally recognized as safe, providing that their maximum effects are attained with minimal change in the organoleptic properties of the food (Viuda-Martos et al., 2008). The essential oils contain many phytochemicals including phenolic compounds like flavonoids, which are sources of natural antioxidants. Their antioxidant activity depends upon their ability to interact with free radicals (Dawidowicz et al., 2006). In addition to antioxidant activity, herbal compounds have antimicrobial, anti-inflammatory, anti-mutagenic and anti-cancer activities, which have positive effects on functionality of foods against diseases (Khader et al., 2010; Liu et al., 2009; Madhuri and Pandey, 2009 and Namsa et al., 2009).

The bark and leaves of Cinnamon are commonly used as spices in the home kitchen and their distilled essential oils or synthetic analogs are used as flavoring agents in the food and beverage industry (Jham et al., 2005). Antifungal and antibacterial principles present in essential oil are effective in preventing food spoilage (Fabio et al., 2007 and Valero and Salmeron, 2003). Cinnamon bark had higher inhibitory zone $(20-40 \mathrm{~mm})$ against five target 
bacteria (Escherichia coli, Listeria monocytogenes, Staphylococcus aureus, and Salmonella typhimurium) and one spoilage bacterium (Pseudomonas aeruginosa) as compared with other essential oils, Cinnamon bark essential oils used in cooked meat was conducted and an essential oil level of $0.05 \%$ was the highest organoleptically acceptable (Ghabraie et al., 2015). Mathew and Abraham (2006) showed that cinnamon extracts contain a number of antioxidant compounds, which could effectively scavenge reactive oxygen species including superoxide anions and hydroxyl radicals as well as other free radicals. Ciftci et al. (2010) suggested that cinnamon oil might play an important role as an endogenous antioxidant metabolism and could be applicable as a protective agent against tissue damage.

Cinnamomum zeylanicum essential oil contains a distinct antioxidant activity, which is attributed to the presence of phenolic and poly-phenolic compounds (Chericoni et al., 2005 and Jayaprakasha et al., 2006). Three of the main components of the essential oils obtained from the bark of $C$. zeylanicum are transcinnamaldehyde, eugenol, and linalool, which represent $82.5 \%$ of the total composition (Chericoni et al., 2005). Trans-cinnamaldehyde, accounts for approximately $49.9-62.8 \%$ of the total amount of bark oil (Singh et al., 2007 and Simic et al., 2004). Trans-cinnamaldehyde as the major constituents of the total amount of bark oil contains relatively high amounts of phenolic compounds (18.2\% of the oil); their phenolic group plays an important role in antioxidant activity, which act as hydrogen donor (ElBaroty et al., 2010 and Shen et al., 2012). The Cinnamomum zeylanicum essential oil acted as a good inhibitor of primary and secondary oxidation products formation in mustard oil at the concentration of $0.02 \%$ (Singh et al., 2007). The plant tissue has also strong antioxidant capacity because of richness from some antioxidant vitamins and minerals (Jayaprakasha, 2007 and Gul and Safdar, 2009). Varalakshmi et al. (2012) reported that bark of $C$. zeylanicum was a potential source of natural antioxidants, and could be used in any preparations for combating free radical mediated damage to the body.

Sausage is one of the popular foodstuffs among processed meat products (Barbut, 2001). However, during storage, quality attributes of the product deteriorate due to lipid oxidation and microbial growth. Lipids oxidation is responsible for reduction in nutritional quality as well as changes in flavor (Aguirrezábal et al., 2000), while microbial contamination can pose major public health hazards and economic loss in terms of food poisoning and meat spoilage. Thus, application of suitable agents possessing both antioxidant and antimicrobial activities may be useful for maintaining meat quality, extending shelf life and preventing economic loss (Yin and Cheng, 2003).
The objective of this study was to investigate the antioxidant as well as the antimicrobial effectiveness of two Cinnamomum zeylanicum concentrations $(0.02 \%$ and $0.04 \% \mathrm{v} / \mathrm{w})$ in preserving raw chicken sausage during storage at $4^{\circ} \mathrm{C}$.

\section{MATERIALS AND METHODS}

Extraction of Cinnamomum zeylanicum essential oil: Dried aerial parts of $C$. zeylanicum spice were acquired from a local market. The essential oil of $C$. zeylanicum was extracted by hydro-distillation, using a modified Clevenger apparatus method. Plant material was added to water in a $2 \mathrm{~L}$ volumetric distillation flask and coupled to the altered Clevenger device and the extraction was performed for $2.5 \mathrm{hrs}$. at $100{ }^{\circ} \mathrm{C}$. The essential oil was collected and the remaining water were removed with anhydrous sodium sulfate. The oil was stored at $4^{\circ} \mathrm{C}$ in glass flasks wrapped in aluminum foil. (Oliveira et al., 2010).

\section{Preparation of chicken sausage:}

The chicken sausage was produced with boneless chicken meat purchased from a local commercial source. The chicken meat and immediate subcutaneous fat, which was scraped from the outermost layer of skin, were ground together through a $0.4-\mathrm{cm}$ grinder plate (Super grinder-MK-G3; Matsushita Electric Industrial, Japan). The mass of the sausage was divided into three separate lots, BHA-formulated sausage samples (T1), sausage with $C$. zeylanicum essential oil $0.02 \%$ v/w (T2) and sausage with C. zeylanicum essential oil $0.04 \% \mathrm{v} / \mathrm{w}$ (T3). Butylated hydroxyanisole (BHA) was purchased from El Gomhoria Pharmaceutical Com. and used as a reference antioxidant. It was added to the sausage formulation at a concentration of $0.1 \mathrm{~g} / \mathrm{kg}$ (USDA, 1999).

All other ingredients were added in equal amounts $(\mathrm{g} / \mathrm{kg})$ to the various formulations of sausage meat: 100 $\mathrm{g}$ shattered ice, $20 \mathrm{~g}$ salt (sodium chloride), $1.5 \mathrm{~g}$ sodium polyphosphate, $1 \mathrm{~g}$ monosodium glutamate, 0.1 $\mathrm{g}$ sodium nitrate, and $6.2 \mathrm{~g}$ sausage seasoning $(3.5 \mathrm{~g}$ white pepper, $1.5 \mathrm{~g}$ nutmeg, $0.7 \mathrm{~g}$ sage and $0.5 \mathrm{~g}$ allspice). The batter was mixed in an emulsifier for 3 min and the resulting mixture was stuffed tightly into hydrocellulose casings $1.5 \mathrm{~cm}$ in diameter (Viskase Corporation, Chicago, USA), which were subsequently divided into food-casing lengths of about $12 \mathrm{~cm}$ per unit. The sausage units were packaged in polyethylene bags, labeled and stored for 21 days at $4^{\circ} \mathrm{C}$. The following evaluations were performed on the sausage products $-\mathrm{pH}$, thiobarbituric acid (TBA), aerobic plate count (APC) and sensory panel test at $0,3,6,9,12,15$, 18 and 21 day.

\section{1) PH value}

The $\mathrm{pH}$ of the samples was determined following the method AOAC (1995). The $\mathrm{pH}$ was measured by blending a $10 \mathrm{~g}$ sample with $90 \mathrm{~mL}$ deionized water 
for $2 \mathrm{~min}$. The $\mathrm{pH}$ of the obtained suspension was measured with a digital $\mathrm{pH}$ meter.

\section{2) Lipid oxidation}

Thiobarbituric acid (TBA) assay was carried out according to the procedure of Schmedes and Holmer (1989). Sausage sample (10 g) was mixed with $25 \mathrm{ml}$ of trichloroacetic acid solution $(200 \mathrm{~g} / \mathrm{l}$ of TCA in $135 \mathrm{ml} / \mathrm{l}$ phosphoric acid solution) and homogenized in a blender for $30 \mathrm{~s}$. After filtration, $2 \mathrm{ml}$ of the filtrate were added to $2 \mathrm{ml}$ TBA solution $(3 \mathrm{~g} / \mathrm{l})$ in a test tube. The test tubes were incubated at room temperature in the dark for $20 \mathrm{~h}$; then the absorbance was measured at $532 \mathrm{~nm}$ by using UV-VIS spectrophotometer (model UV-1200, Shimadzu, Japan). TBA value was expressed as $\mathrm{mg}$ malonaldehyde per $\mathrm{kg}$ of sausage.

\section{3) Aerobic plate count}

APC was determined by the method described by APHA (1984). Sausage sample $(10$ g) was homogenized with $90 \mathrm{ml}$ of sterile peptone water $(1 \mathrm{~g} / \mathrm{l})$ in a laboratory homogenizer and serial dilutions were prepared, then $0.1 \mathrm{ml}$ of each dilution was spread with a bent sterile glass rod on duplicate plates of pre-poured and dried standard plate count agar. After 48 -h incubation at $25^{\circ} \mathrm{C}$, colonies were counted and results were expressed as $\log _{10} \mathrm{CFU} / \mathrm{g}$ of sausage sample.

\section{4) Sensory evaluation:}

The investigated samples were evaluated using a panel test of a point hedonic scale (Sendecor and Cochran, 1987). Representative samples of the different sausage formulations were cooked in hot water at $75^{\circ} \mathrm{C}$ for 25 min. The intensity of $C$. zeylanicum odor, taste, tenderness and overall acceptability scores of the sausage were determined by 10 panelists. Samples were cut into uniform size (about $3 \mathrm{~cm}$ in length), and introduced to panelists in covered serving dishes coded with 3-digit random numbers. An eight-point hedonic scoring scale (Sendecor and Cochran, 1987) (8=extremely intense/tender; 7=very intense/tender;
$6=$ moderately intense/tender; $5=$ slightly intense/tender; $4=$ slightly bland/tender; $3=$ =moderately bland/tender; $2=$ very bland/tender; $1=$ extremely bland/tender) was employed for $C$. zeylanicum odor, taste and tenderness intensity of sausage. A nine-point hedonic scale (9=like extremely; $8=$ like very much; 7=like moderately; $6=$ like slightly; 5=neither like nor dislike; 4=dislike slightly; 3 =dislike moderately; 2 =dislike very much; 1=dislike extremely) was used for evaluation of the overall acceptability.

\section{5) Statistical analysis:}

Triplicate samples $(n=3)$ were analyzed for each property. The results were expressed in terms of mean and Stander Error (SE) of mean. Statistical analysis (ANOVA) was applied to the data followed by Duncan's Multiple Range Test (Duncan, 1955) using SPSS software. Differences between means were determined by the least significant difference test, and significance was defined at $P<0.05$.

\section{RESULTS}

\section{1) pH values:}

The $\mathrm{PH}$ values of refrigerated sausage at $4^{\circ} \mathrm{C}$ for samples containing $C$. zeylanicum essential oil and control samples during different periods are presented in Table (1). The initial $\mathrm{pH}$ value was $6.65 \pm 0.02$ in BHA-formulated samples (T1), $6.86 \pm 0.01$ in sausage samples formulated with $C$. zeylanicum essential oil $0.02 \% \mathrm{v} / \mathrm{w}$ (T2) and $6.86 \pm 0.01$ in sausage samples formulated with $C$. zeylanicum essential oil $0.04 \% \mathrm{v} / \mathrm{w}$ (T3). After 21 days of storage, it reached to $6.22 \pm 0.01,6.12 \pm 0.03$ and $6.14 \pm 0.01$ in (T1), (T2) and (T3) respectively. In all sausage formulations, storage had a significant effect $(P<0.05)$ on the $\mathrm{pH}$ values, which tended to increase with storage time. However, after 21 days of storage no significant difference was detected between $\mathrm{pH}$ of BHAformulated samples (T1), samples formulated with $C$. zeylanicum essential oil $0.02 \% \mathrm{v} / \mathrm{w}$ (T2) and samples formulated with $C$. zeylanicum essential oil $0.04 \% \mathrm{v} / \mathrm{w}$ (T3).

Table 1: $\mathrm{pH}$ values of chicken sausage formulated with $C$. zeylanicum essential oil stored at $4^{\circ} \mathrm{C}$ (Mean $\pm \mathrm{SE}$ ).

\begin{tabular}{|c|c|c|c|c|c|c|c|c|}
\hline \multirow{2}{*}{$\begin{array}{l}\text { Storage } \\
\text { (days) }\end{array}$} & \multicolumn{8}{|c|}{$P H$ values $($ Mean $\pm S E)$} \\
\hline & $\mathbf{0}$ & 3 & 6 & 9 & 12 & 15 & 18 & 21 \\
\hline T1 & $6.65 \pm 0.02^{\mathrm{Aa}}$ & $6.39 \pm 0.01^{\mathrm{Aa}}$ & $6.30 \pm 0.06^{\mathrm{Aa}}$ & $6.28 \pm 0.01^{\mathrm{Ab}}$ & $6.28 \pm 0.01^{\mathrm{Ab}}$ & $6.26 \pm 0.01^{\mathrm{Ac}}$ & $6.23 \pm 0.01^{\mathrm{Ac}}$ & $6.22 \pm 0.01^{\mathrm{Ad}}$ \\
\hline $\mathbf{T 2}$ & $6.86 \pm 0.01^{\mathrm{Aa}}$ & $6.83 \pm 0.03^{\mathrm{Aa}}$ & $6.83 \pm 0.01^{\mathrm{Ab}}$ & $6.76 \pm 0.02^{\mathrm{Aa}}$ & $6.71 \pm 0.01^{\mathrm{Ab}}$ & $6.68 \pm 0.01^{\mathrm{Ac}}$ & $6.38 \pm 0.01^{\mathrm{Ac}}$ & $6.12 \pm 0.03^{\mathrm{Ad}}$ \\
\hline $\mathbf{T 3}$ & $6.86 \pm 0.01^{\mathrm{Aa}}$ & $6.84 \pm 0.01^{\mathrm{Aa}}$ & $6.77 \pm 0.01^{\mathrm{Ab}}$ & $6.71 \pm 0.01^{\mathrm{Aa}}$ & $6.63 \pm 0.02^{\mathrm{Ab}}$ & $6.58 \pm 0.01^{\mathrm{Ac}}$ & $6.39 \pm 0.01^{\mathrm{Ac}}$ & $6.14 \pm 0.01^{\mathrm{Ad}}$ \\
\hline \multicolumn{9}{|c|}{$\begin{array}{l}\mathrm{AB} \text { Values followed by different capital letter within the same column are significantly different }(P<0.05) \text {. } \\
\text { abcd Values followed by different small letter within the same row are significantly different }(P<0.05) \text {. }\end{array}$} \\
\hline \multicolumn{9}{|c|}{$\begin{array}{l}\text { T1= BHA-formulated sausage samples, } \quad \mathrm{T} 2=\text { sausage samples formulated with } C . \text { zeylanicum essential oil } \\
0.02 \% \mathrm{v} / \mathrm{w}\end{array}$} \\
\hline
\end{tabular}




\section{2) Lipid oxidation:}

Table (2) shows the effect of $C$. zeylanicum essential oil addition and storage time on the lipid oxidation of chicken sausage. The initial TBA value was $0.140 \pm 0.01 \mathrm{mg}$ malonaldehyde $/ \mathrm{Kg}$ sample in BHAformulated samples (T1), 0.138 $\pm 0.02 \quad \mathrm{mg}$ malonaldehyde/Kg sample in sausage samples formulated with $C$. zeylanicum essential oil $0.02 \% \mathrm{v} / \mathrm{w}$ (T2) and $0.139 \pm 0.01$ malonaldehyde/Kg sample in sausage samples formulated with $C$. zeylanicum essential oil $0.04 \% \mathrm{v} / \mathrm{w}$ (T3). After 21 days of storage, it reached to $0.191 \pm 0.02,0.227 \pm 0.02$ and $0.153 \pm 0.02$ mg malonaldehyde/Kg sample in (T1), (T2) and (T3) respectively. All samples had lower TBARs values and adding $C$. zeylanicum essential oil decreased the lipid oxidation of samples. A significant difference was noted between (T2) and (T3) formulated samples, Also a significant difference was noted between (T1) and (T3) where, there is a little increase in TBA values in (T1) and (T2) than (T3) samples during the 21 days of storage.

Table 2: Effect of $C$. zeylanicum on thiobarbituric acid reactive substances (TBARs) values of chicken sausage during 21 days of storage at $4^{\circ} \mathrm{C}($ Mean $\pm \mathrm{SE})$.

\begin{tabular}{|c|c|c|c|c|c|c|}
\hline \multirow{2}{*}{$\begin{array}{c}\text { Storage } \\
\text { days }\end{array}$} & \multicolumn{6}{|c|}{ TBA mg Malonaldehyde/Kg \pm SE } \\
\hline & 3 & 6 & 9 & 12 & 15 & 21 \\
\hline $\mathbf{T 1}$ & $0.140 \pm 0.01^{\mathrm{Aa}} 0.152 \pm 0.01^{\mathrm{Aa}}$ & $0.161 \pm 0.01^{\mathrm{Bb}}$ & $0.172 \pm 0.01^{\mathrm{Bc}}$ & $0.177 \pm 0.01^{\mathrm{Bc}}$ & $0.182 \pm 0.03^{\mathrm{Cd}}$ & $0.186 \pm 0.02^{\mathrm{Cd}} \quad 0.191 \pm 0.02$ \\
\hline $\mathbf{T 2}$ & $0.138 \pm 0.02^{\mathrm{Aa}} 0.163 \pm 0.02^{\mathrm{Ab}}$ & $0.176 \pm 0.01^{\mathrm{Bb}}$ & $0.182 \pm 0.02^{\mathrm{Bb}}$ & $0.191 \pm 0.01^{\mathrm{Bc}}$ & $0.224 \pm 0.01^{\mathrm{Dc}}$ & $0.223 \pm 0.01^{\mathrm{Dc}} \quad 0.227 \pm 0.02^{\mathrm{D}}$ \\
\hline T3 & $0.139 \pm 0.01^{\mathrm{Aa}} 0.140 \pm 0.01^{\mathrm{Aa}}$ & $0.140 \pm 0.00^{\mathrm{Aa}}$ & $0.142 \pm 0.01^{\mathrm{Ab}}$ & $0.143 \pm 0.02^{\mathrm{Bb}}$ & $0.146 \pm 0.01^{\mathrm{Bc}}$ & $0.148 \pm 0.02^{\mathrm{Bc}} \quad 0.153 \pm 0.02^{\mathrm{C}}$ \\
\hline \multicolumn{7}{|c|}{$\begin{array}{l}\text { T1= BHA-formulated sausage samples, } \quad \mathrm{T} 2=\text { sausage samples formulated with } C \text {. zeylanicum essential oil } \\
0.02 \% \mathrm{v} / \mathrm{w} \\
\mathrm{T} 3=\text { sausage samples formulated with C. zeylanicum essential oil } 0.04 \% \mathrm{v} / \mathrm{w}\end{array}$} \\
\hline \multicolumn{7}{|c|}{$\begin{array}{ll}\text { 3) Aerobic plate count } & \text { by ICMSF (1986). At storage day 21, sausage } \\
\text { Initial aerobic plate count (APC) in the sausage was } & \text { samples formulated with C. zeylanicum essential oil } \\
4.41 \log _{10} \mathrm{CFU} / \mathrm{g} \text {; and during the first } 10 \text { days of } & (\mathrm{T} 2 \& \mathrm{~T} 3) \text { maintained lower APC }(6.90 \pm 0.06 \text { and } \\
\text { storage, the count in all sausage formulations } & 6.30 \pm 0.09 \log _{10} \mathrm{CFU} / \mathrm{g} \text {, respectively) than the MPL, } \\
\text { remained below } 7 \log _{10} \mathrm{CFU} / \mathrm{g} \text {, which is the MPL } & \text { while APC in control samples (T1) exceeded the limit } \\
\text { (Maximal Permissible Limit) for APC recommended } & \text { of } 7 \log _{10} \mathrm{C}-\mathrm{FU} / \mathrm{g} \text {. }\end{array}$} \\
\hline
\end{tabular}

Table 3: Effect of $C$. zeylanicum on aerobic plate count (APC) of chicken sausage, during 21 days of storage at $4^{\circ} \mathrm{C}($ Mean $\pm \mathrm{SE})$.

\begin{tabular}{|c|c|c|c|c|c|c|c|c|}
\hline \multirow{2}{*}{$\begin{array}{c}\text { Storage } \\
\text { days }\end{array}$} & \multicolumn{8}{|c|}{ APC log cfu/g \pm SE } \\
\hline & $\mathbf{0}$ & 3 & 6 & 9 & 12 & 15 & 18 & 21 \\
\hline $\mathbf{T 1}$ & $4.40 \pm 0.01^{\mathrm{Aa}}$ & $4.97 \pm 0.02^{\mathrm{Ab}}$ & $5.41 \pm 0.09^{\mathrm{Bb}}$ & $6.19 \pm 0.05^{\mathrm{Cc}}$ & $6.82 \pm 0.05^{\mathrm{Cd}}$ & $7.24 \pm 0.08^{\mathrm{Cd}}$ & $7.82 \pm 0.03^{\mathrm{Cd}}$ & $8.52 \pm 0.07^{\mathrm{De}}$ \\
\hline $\mathbf{T 2}$ & $4.39 \pm 0.02^{\mathrm{Aa}}$ & $4.83 \pm 0.04^{\mathrm{Ab}}$ & $4.87 \pm 0.02^{\mathrm{Ab}}$ & $5.30 \pm 0.06^{\mathrm{Bc}}$ & $5.54 \pm 0.02^{\mathrm{Bc}}$ & $6.14 \pm 0.05^{\mathrm{Cc}}$ & $6.49 \pm 0.03^{\mathrm{Cc}}$ & $6.90 \pm 0.06^{\mathrm{Cd}}$ \\
\hline T3 & $4.45 \pm 0.01^{\mathrm{Aa}}$ & $4.83 \pm 0.01^{\mathrm{Ab}}$ & $4.87 \pm 0.02^{\mathrm{Ab}}$ & $5.15 \pm 0.09^{\mathrm{Bc}}$ & $5.51 \pm 0.06^{\mathrm{Bc}}$ & $5.81 \pm 0.04^{\mathrm{Bd}}$ & $5.93 \pm 0.04^{\mathrm{Bd}}$ & $6.30 \pm 0.09^{\mathrm{Ce}}$ \\
\hline $\begin{array}{l}{ }^{\mathrm{ABCD}} \mathrm{V} \\
\text { abcde } \mathrm{V} \\
\mathrm{T} 1=\mathrm{B} \\
0.02 \%\end{array}$ & $\begin{array}{l}\text { alues followe } \\
\text { lues followe } \\
\text { HA-formulate } \\
\text { v/w }\end{array}$ & $\begin{array}{l}\text { by different } \\
\text { by different } \\
\text { sausage sam }\end{array}$ & $\begin{array}{l}\text { capital letter } \\
\text { small letter w } \\
\text { les, }\end{array}$ & $\begin{array}{l}\text { vithin the sar } \\
\text { hin the same } \\
\text { = sausage sam }\end{array}$ & $\begin{array}{l}\text { ne column ar } \\
\text { row are sign } \\
\text { ples formulat }\end{array}$ & $\begin{array}{l}\text { significantly } \\
\text { ficantly diffe } \\
\text { d with } C \text {. zeyl }\end{array}$ & $\begin{array}{l}\text { different }(P \\
\text { ent }(P<0.05 \\
\text { anicum essen }\end{array}$ & ial oil \\
\hline
\end{tabular}




\section{4) Sensory evaluation:}

The results of sensory assessment of chicken sausage formulated with $C$. zeylanicum essential oil samples are shown in Table (4). In general, samples with $C$. zeylanicum essential oil had the higher scores than control sample. Regarding to odor, the score of $C$. zeylanicum essential oil $0.04 \%$ sample was significantly higher than other samples $(p<0.05)$. The taste and overall acceptability scores of samples with C. zeylanicum essential oil were higher than control one, but there were no significant difference between them $(p>0.05)$. The tenderness of all samples was not significantly affected by addition $C$. zeylanicum essential oil $(p>0.05)$.

Table 4: Mean scores of sensory characteristics of cooked sausage formulated with C. zeylanicum essential oil.

\begin{tabular}{cccc}
\hline Sensory attributes & \multicolumn{3}{c}{ Sensory scores } \\
\cline { 2 - 4 } & $\mathbf{T 1}$ & $\mathbf{T 2}$ & T3 \\
\hline Taste & $5.57 \pm 2.00$ & $6.42 \pm 1.74$ & $6.61 \pm 1.61$ \\
\hline Odor & $6.42 \pm 1.34$ & $6.52 \pm 1.16$ & $6.61 \pm 1.28$ \\
\hline Tenderness & $6.00 \pm 1.81$ & $6.72 \pm 1.44$ & $6.73 \pm 1.69$ \\
\hline Overall acceptability & $5.68 \pm 0.47$ & $6.15 \pm 0.68$ & $6.94 \pm 1.39$
\end{tabular}

T1= BHA-formulated sausage samples,

$\mathrm{T} 2=$ sausage samples formulated with $C$. zeylanicum essential oil $0.02 \% \mathrm{v} / \mathrm{w}$

T3= sausage samples formulated with $C$. zeylanicum essential oil $0.04 \% \mathrm{v} / \mathrm{w}$

\section{DISCUSSION}

\section{1) pH values:}

Regarding to $\mathrm{pH}$ values, C. zeylanicum essential oil did not show statistically significant effect $(p>0.05)$ on $\mathrm{pH}$ in each day of storage days between the control (T1) and samples containing $C$. zeylanicum essential oil at two concentrations (T2 \& T3), while time was the most influential factor in this respect. In the control (T1), $C$. zeylanicum essential oil $0.02 \%$ samples (T2) and $C$. zeylanicum essential oil $0.04 \%$ sample (T3), the $\mathrm{pH}$ significantly decreased from $6.65,6.86$ and 6.86 at day 0 to $6.22,6.12$ and 6.14, respectively, at day $21(p<0.05)$. This phenomenon may have been due to the fall in $\mathrm{pH}$ coincided with the more growth of lactic acid bacteria in control sample in compare with other samples, which would lead to more lactic acid production (Viuda-Martos et al., 2010).

\section{2) Lipid oxidation:}

TBA value is routinely used as an index of lipid oxidation in meat products in store (Raharjo and Sofos, 1993), and the rancid flavor is initially detected in meat products between TBA values of 0.5 and $2.0 \mathrm{mg}$ malonaldehyde/Kg sample (Gray and Pearson, 1987). The TBA values for the refrigerated chicken sausage at $4^{\circ} \mathrm{C}$ are presented in Table (2).

All examined samples in (T1), (T2) and (T3) had lower TBARs values and adding $C$. zeylanicum essential oil decreased the lipid oxidation of samples. A significant difference was noted between (T2) and (T3) formulated samples, also a significant difference was noted between (T1) and (T3) where, there is a little increase in TBA values in (T1) than (T3) and (T2) than (T3) samples during the 21 days of storage. Such activity is basically due to the composition of essential oils: mainly to flavonoids and phenolic compounds. Flavonoids act as antioxidants because their structural features like scavenging lipid peroxy radicals by donating hydrogen and become more stable phenoxy radicals (Choe and Min, 2009). Spice essential oils with antioxidant activities may also interfere with the propagation reactions (Russo et al., 2000) besides inhibiting the enzymatic systems involved in initiation reactions (You et al., 1999). In addition, they can act as the hydrogen donor, scavengers of free radicals, metallic ion chelation or even acting as substrate of radicals such as superoxide or hydroxyl (Al-Mamary et al., 2002).

\section{3) Aerobic plate count:}

Initial aerobic plate count (APC) in the sausage was $4.41 \log _{10} \mathrm{CFU} / \mathrm{g}$; and during the first 10 days of storage the count in all sausage formulations remained below $7 \log _{10} \mathrm{CFU} / \mathrm{g}$ which is the MPL (Maximal Permissible Limit) for APC recommended (ICMSF, 1986).

Table (3) shows at storage day 21, chicken sausage samples formulated with $C$. zeylanicum essential oil either $0.02 \%$ (T2) or $0.04 \%$ (T3) maintained lower APC $\quad 6.90 \pm 0.06$ and $6.30 \pm 0.09 \quad \log _{10} \mathrm{CFU} / \mathrm{g}$, respectively) than the MPL, while APC in BHA formulated samples (T1) exceeded the limit of $7 \log _{10}$ $\mathrm{C}-\mathrm{FU} / \mathrm{g}$ by $1.52 \pm 0.07$ logs. The anti-microbial action is considered to arise mainly from the potential of hydrophobic essential oils to obstruct the bacterial 
cell membrane and its structures, which leads to ion leakage. It has been proposed that eugenol and cinnamaldehyde inhibit production of an essential enzyme by the bacteria and/or cause damage to the cell wall of bacteria (Burt, 2004).

This result is agree with the result obtained by Jagadeesh Babu et al. (2012), they found that In chicken meat patties treated with essential oil of cinnamon, the Staphylococcus aureus counts were significantly $(\mathrm{P}<0.05)$ different from control. Among the treatment groups chicken meat patties treated with essential oil of cinnamon at 1:250 and 1:500 concentrations recorded significantly $(\mathrm{P}<0.05)$ lower counts of Staphylococcus aureus during the storage period. The decreased Staphylococcus aureus count may be due to cinnamaldehyde the antimicrobial compound of cinnamon. Since the essential oil of cinnamon gave similar results even at lesser concentration (i.e.at 1:500) it is considered as having the best antimicrobial effect in this study. Also, the result of this study was similar to the findings of Hoque et al. (2007) who found that essential oil of cinnamon at 10 percent concentration showed highest antimicrobial effect and Sema agaoglu et al. (2007) reported that diethyl ether treated cinnamon extract was found to be most effective against Staphylococcus aureus.

\section{4) Sensory evaluation:}

According to the results of sensory evaluation, samples with $C$. zeylanicum essential oil had the higher scores than control ones in all of sensory attributes. These results are agree with the results obtained by (Erich et al., 2006) and (Estévez et al., 2005), they reported that addition of natural essential oils have been enhance sensory characteristics of emulsion type meat products by reducing hardness, adhesiveness, gumminess and chewiness. In addition, the results of the present study showed that the odor of samples was not significantly affected by adding $C$. zeylanicum essential oil ( $p>0.05)$. In agreement with our findings, it has been reported that overall acceptability of fish fillet sample coated with solution containing $C$. zeylanicum essential oil was higher than control sample at $16^{\text {th }}$ day (Ojagh et al., 2010).

\section{CONCLUSION}

This study concluded that C. zeylanicum essential oil provide antioxidant and antimicrobial benefits to raw chicken sausage during cold storage $\left(4^{\circ} \mathrm{C}\right)$. The addition of spice essential oils such as C. zeylanicum seems to be a technologically viable alternative for elaborating cooked meat products because the natural image of the products is improved. In the case of chicken sausage, $C$. zeylanicum essential oil improve acceptance and have desirable effects as regards oxidative stability. The addition of $C$. zeylanicum essential oil alone and in combination with other preservative agents and methods (such as other plant-originated antioxidant agents or vacuum packaging) should be considered as a good method to improve chemical characteristics of chicken sausage.

\section{REFERENCES}

Aguirrezábal, M.M.; Mateo, J.; Domínguez, M.C. and Zumalacárregui, J.M. (2000): The effect of paprika, garlic and salt on rancidity in dry sausages. Meat Science. 54: 77-81.

Al-Mamary, M.; Al-Meeri, A. and Al-Habori, M. (2002): Antioxidant activities and total phenolics of different types of honey. Nutr. Res.; 22: 1041-1047.

AOAC (1995): Official methods of analysis of AOAC International. 2 vols. 16th edition. Arlington, VA, USA, Association of Analytical Communities.

APHA (1984): Compendium of Methods for the Microbiological Examination of Foods. $6^{\text {th }}$ Edn., American Public Health Association, Washington, D.C., pp: 919-927.

Barbut, S. (2001): Poultry products processing: An industry guide. 1st ed. Boca Raton, FL, USA: CRC Press.

Burt, S. (2004): Essential oils: their antibacterial properties and potential applications in foods - a review, International Journal of Food Microbiology, Vol. 94, no. 3, pp. 223-253.

Chericoni, S.; Prieto, J.M.; Iacopini, P. (2005): In vitro activity of the essential oil of Cinnamomum zeylanicum and eugenol in peroxynitrite-induced oxidation processes. J Agric. Food Chem.; 53: 4762-4765.

Choe, E. and Min, D.B. (2009): Mechanisms of antioxidants in the oxidation of foods. Comp Rev. Food Sci. Food Safety; 8: 345-358.

Ciftci, M.; Simsek, U.G.; Yuce, A.; Yilmaz, O. and Dalkilic, B. (2010): Effects of dietary antibiotic and cinnamon oil supplementation on antioxidant enzyme activities, cholesterol levels and fatty acid compositions of serum and meat in broiler chickens. Acta Vet Brno, 79, 33-40.

Dawidowicz, A.L.; Wianowska, D. and Baraniak B. (2006): The antioxidant properties of alcoholic extracts from Sambucus nigra L (antioxidant properties of extracts) LWT Food Sci. Technol.; 39: 308-315.

Duncan, D.R. (1955): Multiple ranges and multiple F test. Biometrics.11: 31-42.

El-Baroty, G.S.; Abdel-Baky, H.H.; Farag, R.S. and Saleh, MA. (2010): Characterization of antioxidant and antimicrobial compounds of cinnamon and ginger essential oils Afr $J$ Biochem Res, 4, 167-174.

Erich, S.; Leopold, J.; Gerhard, B. (2006): Composition and antioxidant activities of the essential oil of cinnamon (Cinnamomum 
zeylanicum Blume) leaves from Sri Lanka. J. Essent Oil Bear P1. 9(2): 170-182.

Estévez, M.; Ventanas, S. and Cava, R. (2005): Protein oxidation in frankfurters with increasing levels of added rosemary essential oil: Effect on color and texture deterioration. J. Food Sci. 70: C427-C432.

Fabio, A.; Cermelli, C.; Fabio, G.; Nicoletti, P. and Quaglio, P. (2007): Screening of the antibacterial effects of a variety of essential oils on microorganisms responsible for respiratory infections. Phytother. Res.; 21: 374-377.

Ghabraie, M.; Khanh D.V.; Lina T.; Stéphane S. and Monique L. (2015): Antimicrobial effect of essential oils in combinations against five bacteria and their effect on sensorial quality of ground meat. Food Science and Technology. Volume 63, Issue 2, pp. 799-1354.

Gray, J.I. and Pearson, A.M. (1987): Rancidity and warmed-over flavor. In: Pearson AM, Dutson TR, editors. Advances in meat research. Vol. 3. NY, USA: Van Nostrand Company. pp. 221-269.

Gul, S. and Safdar, M. (2009): Proximate composition and mineral analysis of cinnamon. Pakistan J. Nutr, 8, 1456-1460.

Hoque, M.D.; Inatsu, M.L.; Juneja Vijay. and Kawamoto, S. (2007): Antimicrobial activity of clove and cinnamon extracts against food borne pathogens and spoilage bacteria and inactivation of Listeria monocytogenes in ground chicken meat with their essential oils. Journal of Food Science \& Technology.72: 921.

ICMSF (1986): Microorganisms in foods. 2. Sampling for microbiological analysis: Principles and specific applications. $2^{\text {nd }}$ ed. Toronto: University of Toronto Press.

Ito, N.; Fukushima, S.; Tamano, S.; Hiroe, M. and Hagiwara, A. (1986): Dose response in butylated hydroxyanisole induction of forestomach carcinogenesis in F 344 rats. J Natl Cancer Inst.; 77: 1261-1265.

Jagadeesh Babu, A.; Rupasundari, A.; Sankar Reddy, B. and Sravanthi, M. (2012): Studies on the antimicrobial effectiveness of essential oils of garlic, clove and cinnamon on Staphylococcus aureus in chicken meat patties. Tamilnadu J. Veterinary and Animal Sciences 8 (1) 45-49.

Jayaprakasha, G.K.; Negi, P.S.; Jena, B.S. and Jagan Mohan Rao, L. (2007): Anti-oxidant and antimutagenic activities of Cinnamomum zeylanicum fruit extracts. J. Food Compos Anal, 20, 330-336.

Jayaprakasha, G.K.; Ohnishi-Kameyama, M. and Ono, H. (2006): Phenolic constituents in the fruits of Cinnamomum zeylanicum and their antioxidant activity. J. Agric. Food Chem.; 54: 1672-1679.
Jham, G.N.; Dhingra, O.D.; Jardin, C.M. and Valente, M.M. (2005): Identification of the major fungi toxic component of cinnamon bark oil. Fitopatol Bras.; 30: 404408.

Khader, M.; Bresgen, N. and Eckl, P.M. (2010): Antimutagenic effects of ethanolic extracts from selected Palestinian medicinal plants. J. Ethnopharmacol. 127: 319-324.

Liu, X.; Zhao, M. and Wang, J. (2009): Antimicrobial and antioxidant activity of Emblica extracts obtained by supercritical carbon dioxide extraction and methanol extraction. J. Food Biochem. 33: 307-330.

Madhuri, S. and Pandey, G. (2009): Some anticancer medicinal plants of foreign origin. Curr Sci.; 96: 779-783.

Mathew, S. and Abraham, T.E. (2006): Studies on the antioxidant activities of cinnamon (Cinnamomum verum) bark extracts, through various in vitro models. Food Chem.; 94: 520 528.

Namsa, N.D.; Tag, H. and Mandal, M. (2009): An ethnobotanical study of traditional antiinflammatory plants used by the Lohit community o Arunachal Pradesh. India J. Ethnopharmacol. 125: 234-245.

Ojagh, S.M.; Rezaei, M. and Razavi, S.H. (2010): Effect of chitosan coatings enriched with cinnamon oil on the quality of refrigerated rainbow trout. Food Chem.; 120: 193-198.

Oliveira, M.M.M.; Brugnera, D.F. and Cardoso, M.G. (2010): Disinfectant action of Cymbopogon sp essential oils in different phases of biofilm formation by Listeria monocytogenes on stainless steel surface. Food Control; 21: 549-553.

Raharjo, S. and Sofos J.N. (1993): Methodology for measuring malonaldehyde as a product of lipid peroxidation in muscle tissues: A review. Meat Science; 35: 145-169.

Russo, A.; Acquaviva, R. and Campisi, A. (2000): Bioflavonoids as antiradicals, antioxidants and DNA cleavage protectors. Cell Biol Toxicol. 16(2): 91-98.

Schmedes A. and Holmer G. (1989): A new thiobarbituric acid (TBA) method for determination of free malonaldehyde (MDA) and hydroperoxides selectivity as a measure of lipid peroxidation. Journal of American Oil Chemistry Society.66: 813-817.

Sebranek, J.G.; Sewalt, V.J.H. and Robbins, K.L. (2005): Comparison of a natural rosemary extract and BHA/BHT for relative antioxidant effectiveness in pork sausage. Meat Sci.; 69: 289-296.

Sebranek, J.G.; Sewalt, V.J.H. and Robbins, K.L. (2005): Comparison of a natural rosemary extract and BHA/BHT for relative antioxidant effectiveness in pork sausage. Meat Sci.; 69: 289-296. 
Sema, A.; Nursel, D. and Suleyman, A. (2007): Antimicrobial activity of some spices used in the meat industry. Bull Vet Inst Pulaway 51: 53-57.

Sendecor, G.W. and Cochran, W.G. (1987): Statistical methods ( $7^{\text {th }}$ Edn.). Ames, IA, USA: The Iowa State. University Press, pp: 221-222.

Simic, A.; Sokovic, M.D.; Ristic, M.; GrujicJovanovic S.; Vukojevic, J. and Marin, P.D. (2004): The chemical composition of some lauraceae essential oils and their antifungal activities. Phytother Res , 18: 713-717.

Singh, G.; Maurya, S. and De Lampasona, M.P. (2007): A comparison of chemical, antioxidant and antimicrobial studies of cinnamon leaf and bark volatile oils, oleoresins and their constituents. Food Chem Toxicol. 45: 16501661.

Shen, Y.; Jia, L.N.; Honma, N.; Hosono, T.; Ariga, T. and Seki, T. (2012): Beneficial effects of cinnamon on the metabolic syndrome, inflammation, and pain, and mechanisms underlying these effects. J. Tradit Complement Med, 2, 27-32.

USDA (1999): "United States Department of Agriculture" Nutrient database for standard reference, release 13 .

Valero, M. and Salmeron, M.C. (2003): Antibacterial activity of 11- essential oils against Bacillus cereus in tyndallized carrot broth. Int. J. Food Microbiol. 85: 73-81.
Varalakshmi, B.; Anandh, A.V.; Prasanna, R. and Vijayakumar, K. (2012): Anti-oxidant status of Cinnamomum zeylanicum linn bark. Int $J$ Univers Pharm Life Sci, 2, 409-421.

Viuda-Martos, M.; Ruiz-Navajas, Y. and FernandezLopez, J. (2008): Antifungal activity of lemon (Citrus lemon L) mandarin (Citrus reticulate L) grapefruit (Citrus paradisi L) and orange (Citrus sinensis L) essential oils. Food Control. 19: 1130-1138.

Viuda-Martos, M.; Ruiz-Navajas, Y. and FernandezLopez, J. (2009): Effect of orange dietary fiber, oregano essential oil and packaging conditions on shelf-life of bologna sausages. Food Control. 21(4): 436-443.

Viuda-Martos, M.; Ruiz-Navajas Y. and FernándezLópez, J. (2010): Effect of added citrus fiber and spice essential oils on quality characteristics and shelf-life of mortadella. Meat Sci.; 85: 568-657.

Yin, M.C. and Cheng, W.S. (2003): Antioxidant and antimicrobial effects of four garlic derived organosulfur compounds in ground beef. Meat Science. 63: 23-28.

You, K.M.; Jong, H.G. and Kim, H.P. (1999): Inhibition of cyclo-oxygenase /lipoxygenase from human platelets by polyhydroxylated/ methoxylated flavonoids isolated from medicinal plants. Arch Pharm Res.; 22(1): $18-24$.

\section{دراسة تأثير زيت القرفة على جودة سجق الاجاج

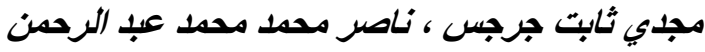

E-mail: magdy.thabet@yahoo.com Assiut University web-site: www.aun.edu.eg

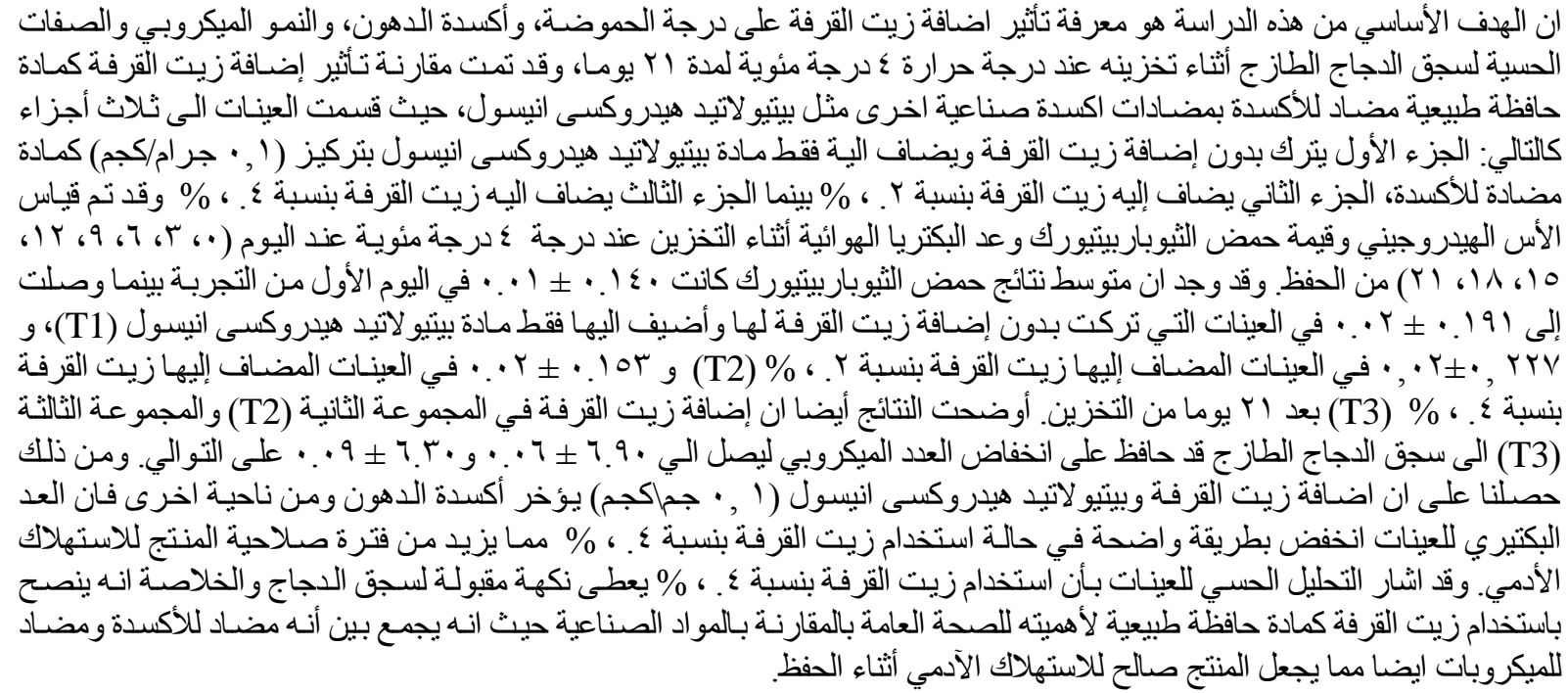

